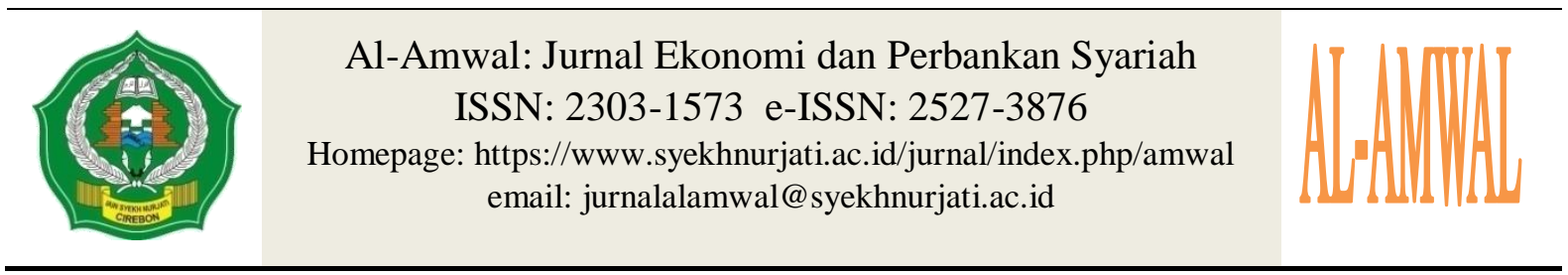

\title{
A rational irrationality: Reviewing the Concept of Rationality in Conventional Economics and Islamic Economics
}

\author{
Muhammad Hasyim Ibnu Abbas \\ Universitas Negeri Malang \\ e-mail: muhammad.hasyim.fe@um.ac.id
}

\begin{abstract}
In analyzing economic phenomena that occur in the midst of society, economists always use assumptions. Rationality is the most important assumption and becomes the main step in analyzing the phenomenon. Individuals in making decisions are assumed to be rational. Problems arise when rational human measurements for the economy of the classical generation are selfish and tend to be selfish. This article discusses how the assumption of rationality is debated among the three major streams of economics today. The three streams referred to are Classical-Neoclassical Economist, Behavioral Economist, and Islamic Economist. Neoclassical-Economist with the assumption that rational individuals are individuals who are concerned with personal desires, Economists of Behavior with the theory of Bounded-Rationality, and Islamic Economists with the argument that the main goal of humans is God.
\end{abstract}

Keywords: Rationality, Classical Economist, Behaviorist, Islamic Economists

\begin{abstract}
Abstrak
Dalam menganalisis fenomena-fenomena ekonomi yang terjadi di tengah-tengah masyarakat, para ekonom selalu menggunakan asumsi. Rasionalitas merupakan asumsi paling penting dan menjadi pijakan utama dalam menganalisis fenomena tersebut. Individu dalam mengambil keputusan-keputusan diasumsikan rasional. Permasalahan muncul ketika ukuran manusia yang rasional bagi ekonomi generasi klasik adalah individu yang mementingkan diri-sendiri dan cenderung bersifat egois. Artikel ini membahas tentang bagaimana asumsi rasionalitas menjadi perdebatan diantara tiga aliran besar ilmu ekonomi saat ini. Tiga aliran yang dimaksud adalah Ekonom Klasik-Neoklasik, Ekonom Keprilakuan, dan Ekonom Islam. Ekonom Klasik-Neoklasik dengan anggapan bahwa individu yang rasional adalah individu yang mementingkan hasrat pribadi, Ekonom Keprilakuan dengan teori Rasionalitas-Terbatas, dan Ekonom Islam dengan dalil bahwa tujuan utama manusia adalah Tuhan.
\end{abstract}

Kata kunci: Rasionalitas, Ekonom Klasik, Ekonom Keprilakuan, Ekonom Islam 


\section{INTRODUCTION}

The assumption of rationality is a basic assumption used in all fields of economics. Humans as objects of economic analysis are usually called economic people (economic man) or homo economicus. In economics, all humans are assumed to be rational individuals. Rational individuals according to neo-classical economists, in short, are individuals who base their decisions on a cost-benefit analysis. All the decisions he takes are based on knowledge of what he must pay and how the benefits he will get afterwards.

In its development, new opinions emerged about how the actual assumptions of rationality that had been used as the basis of the theory could be said to be less 'rational' (Simon, 1955). Simon (1955) is one of the pioneers. The emergence of this idea is based on the dissatisfaction of many parties on rational choice theories which assume that decisions made by individuals are based on rational considerations. One reason is that many individuals who take actions that are not in accordance with the assumption of rationality-for example, do not use an accurate cost-benefit analysis-but rather their habits due to imperfect or limited information called the assumption of Bounded-Rationality (Harstad \& Selten, 2014).

Further developments, the world of economic science began to penetrate the Islamic world so that Muslim economists began to postulate economic theories based on the ethics and morals of a Muslim (Mahomedy, 2013; Rudnyckyj, 2011). The ultimate goal of an economic human being in the view of Islam (or what we usually call homo islamicus) is not to maximize maximization (utility maximization) but rather to the benefit of the people (Zaroni, 2012). Each individual will consider every choice and decision based on his devotion to God.

From the explanation above, it can be seen that there are three schools of thought related to economic assumptions that currently go hand in hand in identifying human behavior in making decisions. The first is the assumption of classical-rationality which has been widely used especially by economists in neo-classical schools. Secondly, criticism of the rationality measures used in economic theories led to the emergence of behavioral schools with its 'limited rationality' assumption. Then the third, scientific development in the Muslim world in all fields gave rise to economic theories based on the morals and ethics of a human being and related to his God, so that a Muslim human has his own rationality (henceforth, we will refer to the term 'Islamic rationality'). This paper aims to explain where the three differences lie, how the implications of the 'rationality' assumptions affect the theories postulated by each of the streams that have been mentioned, and how criticism of the three assumptions.

\section{LITERATURE REVIEW \\ The Concepts of Rationality}

Talking about theories in the study of economics will not be separated from assumptions. Assumptions are used to facilitate modeling and forecasting of economic phenomena that exist in the community. The most basic and foremost assumption is that every individual is rational. Although, the provisions of an individual referred to as rational individuals are still debatable. Rational behavior for some individuals is not necessarily rational for some others (Agil, 1989).

Therefore, many opinions and arguments have emerged about how rational humans really are. Among the several propositions that exist and are currently widely used and used as a theoretical foundation in economics, there are three types of rationality, namely the rationality adopted by economists adhering to neo-classical schools, economists of behavioralism (behaviorist), and finally rationality a la Muslims. To make it easier to explain all three, the author gives the terms, in sequence, 'Classic-Rationality', 'Bounded-Rationality', and 'Islamic-Rationality'. 


\section{Classic Rationality}

The main foundation or basic assumptions in modeling and forecasting in the study of classical economics are rational humans (Isfandiar, 2015). The rationality that they postulate is related to the decisions or choices made by an individual. In traditional economic theories, an individual is assumed that he has knowledge or information related to the choices faced. He also assumed to have a preference system that is structured, consistent, and stable. In addition, he also always has the ability to calculate the benefits and costs he must spend to achieve maximum satisfaction, but at a low cost (Burns \& Roszkowska, 2016; Simon, 1955).

Adherents of this assumption are often called rationalists. The theory of this type of rationality is often called the rational choice theory. In economic theory, a choice is said to be rational if the individual or agent chooses the most preferred alternative and is better than the other alternatives. There are four components that form the rational choices (Burns \& Roszkowska, 2016):

a. Optimizing goals. The individual is assumed to be in a situation that requires him to choose. The individual is careful in choosing and considering. A variety of alternative choices were considered, and choices were made against the best alternative he could make (Rabin, 2013).

b. A collection of several possible options to choose from, consisting of all alternatives that can be chosen with certain limitations. These limits are things that are outside the control of the ability of the individual. In the theory of consumer behavior for example, a collection of several choices that might be chosen are consumption choices that are below the budget line (Hedström \& Ylikoski, 2014).

c. The arrangement of preferences, or often known as the axioms of preferences. The axioms of preference consist of (Burns \& Roszkowska, 2016; Stanovich, 2013):

- Completeness. This axiom states that when an individual faces two choices, he can always sort out his preferences from one of the possibilities. For example, when an individual is faced with goods $\mathrm{A}$ and $\mathrm{B}$, he can always determine with certainty from three possibilities: A is preferred over B, B is preferred over A, or A and B are both indifferent.

- Independence. The axiom of independence means that the order or arrangement of an individual's preferences is not influenced by other alternatives. That is, individual preferences for the two choices A and B are not influenced by the existence of alternative goods, for example $\mathrm{C}$.

- Reflexivity. The axiom of reflexivity means that a choice is equally liked when faced with itself. This axiom is actually not very important, because it is definitely an alternative choice of $\mathrm{A}$ as he likes the A itself.

- Transitivity. The axiom of transitivity requires individual choice to be consistent. If the individual prefers $\mathrm{A}$ over $\mathrm{B}$, and prefers $\mathrm{B}$ over $\mathrm{C}$, then the individual prefers $\mathrm{A}$ over C.

The four axioms form the arrangement of preferences which results in an optimal choice. Additional assumptions in preference theory are the assumptions of monotonicity and convexity. Monotonicity means that more (consumed) will be better. While convexity is an assumption that individuals prefer the average to the extreme. This assumption is a generalization of the marginal rate of substitution theory (MRS) which states that individuals will be willing to reduce the consumption of a good in order to increase consumption for other goods.

d. Available information. This information makes the individual aware of the limitations or obstacles he will face in optimizing his utility (Mahomedy, 2013). 
At first glance, it is clear that the individual who is the object of neo-classical analysis only considers what he can, without considering other individuals around him. In other words, the individual is considered as a selfish person (Isfandiar, 2015).

\section{Bounded-Rationality}

The bounded rationality assumption is widely used by behaviorist economics. It has been mentioned at the outset, that the emergence of ideas on this matter is based on the dissatisfaction of many parties over rational choice theories which assume that decisions made by individuals are based on rational considerations (Ashraf, 2018). Individuals in the classical rational choice model are assumed to have a system of preferences that is structured, consistent, and stable, and good calculation ability in calculating all alternative choices he faces, so he can reach the highest point or the most satisfying for himself (Rabin, 2013).

According to Simon (1955), the ability to think of individuals in formulating and solving complex problems that they face is very small when compared to those problems. With cognitive abilities possessed, individuals certainly are not able to optimize their goals. Therefore, an individual often uses the experience he has to determine which alternatives he should choose and which he should ignore (Harstad \& Selten, 2014; Stanovich, 2013).

There are 3 main points that form the basis of behaviorist ideas, namely boundedrationality, bounded-willpower, and bounded-self interest. These three things have a close relationship. The last two terms mentioned (bounded-willpower, and bounded-self interest), are actually a consequence of the first term (bounded-rationality).

Limited rationality, which was first introduced by Simon (1955), refers to the fact that an individual's cognitive abilities are not infinite. Individuals have the ability to count and have limited memory. This assumption states that the individual has special cognitive traits that make it unable to process information that he can rationally (Jolls et al., 1998). An example is an individual who has a fear of ghosts that will make his desire to buy (or willingness to pay) housing adjacent to a cemetery complex be low, even though the price is cheaper than housing that is far from the cemetery.

In addition to showing their limited rationality, individuals also have limited will (or called bounded-willpower). That is, the individual will often still do something in the present even though he knows that in the future it will have unfavorable effects on him (Jolls et al., 1998). For example, in saving behavior, even if an individual is able to calculate the amount that needs to be saved in this year to maximize utility throughout his life, he may not always be able to resist the temptation to spend money. Another example is for a beggar, when he is offered the choice to be given current money of Rp. 1,000.00 or choose 10 times the money, but the money is given one year later. Surely the beggar will prefer Rp. 1,000.00 in the present although it is 10 times smaller if he is willing to wait for one year. We add to the assumption that inflation for the next year, for example, is only 5 percent, rationally (according to the classical schools), a 10-fold amount should be very beneficial for the beggar.

Furthermore, the final fact is that individuals have a bounded self-interest. This reflects important facts about individual decisions based on the nature of the reciprocation. In some circumstances, they care about other people (or maybe act like they care about others), even if it's someone they just met. Individuals will act well to others if the other person also acts well to him, and vice versa, if he is treated someone poorly then he will also behave unfavorably towards that person. Therefore, individuals in economic analysis of behavior can be kinder or even more evil than individuals in neo-classical analysis (Jolls et al., 1998). 


\section{Islamic Rationality}

The next development of the economic world is the emergence of more and more Muslim economists who bring Islamic approaches to economic analysis. In fact, the history of Islamic economics has been initiated and spearheaded by some scientists or what we call ulama 'during the heyday of the Islamic sultanates, one of which is widely known is Ibn Taymiya, Ibn Khaldun, and Imam Al-Ghozali, even though the three were not specifically known as an economist (Mahomedy, 2013). The development of more advanced Islamic economics is focused on financial instruments, it makes it appear as if the main difference between Islamic and conventional economics lies only in the instrument side not in its fundamental aspects and the foundation of thought (Aydin, 2013; Aysan et al., 2018).

Some Islamic economists argue that Islamic economics is the solution to the many failures of neo-classical economics. But some others only consider this Islamic economy as a complement that can go hand in hand with conventional economics. As one of the sciences, Islamic economics introduces that in Islam the individual who becomes the object of analysis is clearly different from the economic thinking of the western world. The concept of individuals in Islamic economics is often known as Homo Islamicus (Ashraf, 2018; Kuran, 1996; Rudnyckyj, 2011).

Human-Islamic existence in economic analysis certainly has different assumptions from the assumptions that exist in economic theories. The concept of Homo Islamicus or Muslims is a human being whose actions and attitudes and behavior are based on Islamic religious rules written in the Qur'an and the Hadith. The behavior of an individual in Islamic economic theory is assumed to be rational on the basis of its compliance with Islamic laws (Islamic sharia) (Agil, 1989; Tan, 2013). In other words, rational individuals in Islamic economics are individuals who try to maximize their utility within the limits or norms of Islamic religion.

Agil (1989) classifies the components in the assumption of rationality in Islamic economics as follows:

a. An individual is said to be rational if he spends no excess money.

b. An individual is said to be rational if he uses his wealth not only for life before death, but also for life after death - namely shodaqoh, infaq, and so on.

c. An individual is said to be rational if the goods he consumes are only those which are permitted according to Islamic law.

d. A rational individual is an individual who performs alms for the wealth he has. Because in Islam, zakat law is mandatory and includes the pillars of Islam..

The implication is that the demand for illicit goods according to Islamic law will be zero. In addition, regarding luxury goods, demand for luxury goods (which are often purchased without consideration of needs) will tend to fall even as individuals get richer. This happens because in Islam it is not recommended to overdo it and for something intoxicating like alcohol is clearly forbidden.

\section{METHODE}

In reviewing the three concepts of rationality postulated by three major schools of economics, I used a descriptive comparative method with a qualitative approach. Comparative research differs from non-comparative research because it tries to draw conclusions beyond a single case and explains the differences and similarities between objects of analysis and the relationship between objects and the background of their contextual conditions. Comparative research studies two or more similar groups, individuals, countries, events or conditions by comparing them with respect to certain characteristics. Through this comparison, comparative research offers a mechanism for understanding and evaluating the factors that shape and change our world. 
In this study, I compare the thesis of classical economics, behavioral economics, and Islamic economics related to the concept of rationality. After explaining the concept of rationality from the three in the previous section, I describe the criticisms directed at each of their thoughts about rationality in discussion section. Then, I made a synthesis of the three concepts of rationality. The conceptual framework of this study is shown by the figure 1:

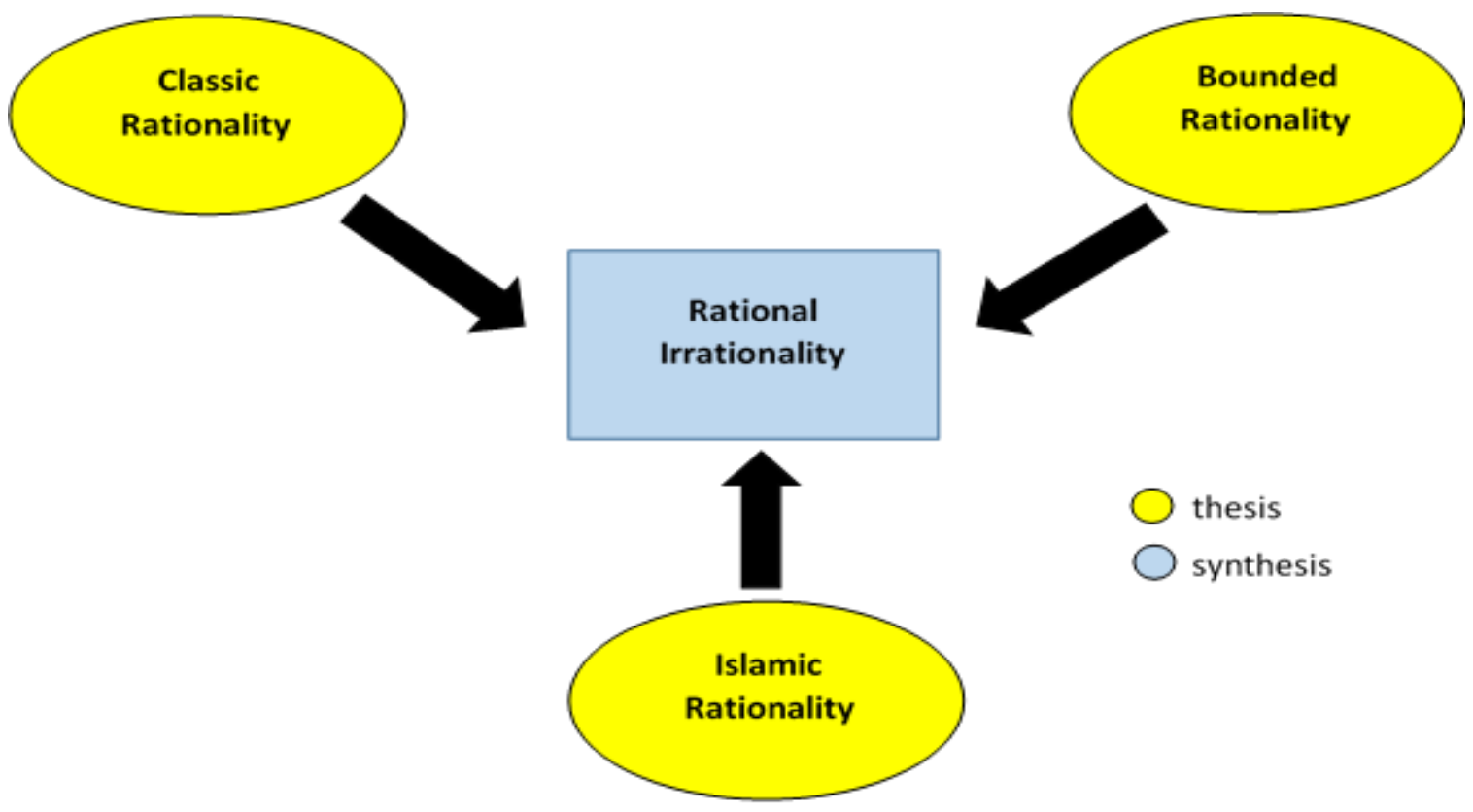

Figure 1. The Conceptual Framework

\section{RESULT AND DISCUSSION \\ Critique to Bounded-Rationality}

The debate about what assumptions are more appropriate and close to reality to postulate theories and predict the actions, behavior, or decisions of an individual will continue because of differences in views and understanding of "rationality". Adherents of classical and / or neoclassical schools explain the rationality of an individual by relying on human nature, namely selfishness and self-centeredness. After several decades the assumption of rationality persisted as an assumption in economic theories, in its development also emerged a criticism of it. Precisely by Simon (1955) with his 'limited-rationality' assumption.

The assumption of limited rationality then develops and becomes the basic assumption of the Behavioral Economics school. Adherents of this school of thought in addition to using elements of human nature as creatures that maximize utility, also include psychological elements in humans. In other words, humans are not only regarded as Homo Economicus but also as Homo Sapiens. Psychological elements included in behavioral analysis are mainly on cognitive elements. Simon, as discussed above, explains that humans are limited creatures in accepting various kinds of information available to choose and then make their choices. Therefore, according to adherents of behaviorism (behaviorist), economic arguments issued by classical and / or neoclassical schools often do not apply.

Even the assumption of limited rationality is not without criticism. One criticism of the 'bounded-rationality', bounded-willpower, bounded self-interest assumptions was made by Richard Posner. About Bounded-Rationality, Posner argues that indeed some individuals often do things that are generally considered irrational, but that does not mean undermining 
the postulates of economic theory (Posner, 2002). For example, from the example mentioned above, about the price of houses adjacent to the cemetery area. People's fears of the funeral complex may depress the price of housing in the vicinity. However, rationalist economic theory will continue to run that is that the need for the property sector is getting higher, making the price even higher, for example, for example, also building educational centers around it so that the location is increasingly crowded. Therefore, even though the housing is close to the cemetery, its proximity to the center of the crowd keeps the housing market price up.

Bounded-Willpower, as the second term in a series of assumptions of limited rationality, describes the nature of humanity that is not always able to withstand its own will (Jolls et al., 1998). But according to Richard Posner, this assumption has actually been included in the economic theory analysis of adherents of classical and neoclassical schools. If we are given the choice to choose between having IDR 1,000.00 in 2017 or IDR 2,000.00 in 2018, then we are likely to prefer IDR 2,000.00 in 2018. But if the choice is replaced and clarified to IDR 1,000 00 today or Rp. 2,000.00 in one year, we will choose Rp. 1,000.00 today. For adherents of behavior, this is an example of bounded-willpower assumptions. According to Richard Posner, this is indeed very natural, but the cause is the lack of information we receive. The money we will receive in one more year will indeed be greater than the money we receive today, but our ignorance (lack of information) on future consumption needs makes us prefer to have less money today because we already know our needs today. In other words, the case only illustrates or explains the cost of information in the economy.

Then, in relation to the assumption of bounded self-interest, Richard Posner (2002) argued that the assumption was merely a repackaging of the interdependent utility function. That is a condition where the welfare or satisfaction of an individual can affect the welfare or satisfaction of other individuals, both positively and negatively. That is, when your satisfaction has a positive impact on my satisfaction, then I will help you achieve your satisfaction. Conversely, if your satisfaction has a negative impact on my utility function, then I will try to reduce your satisfaction. However, adherents of behavioral economics do not consider this at all, they merely postulate that an individual will reciprocate what others do.

\section{What Islamic Economist Said?}

As explained above, Islam views the economy not only from the considerations of an individual or economic agent who is worldly, but also considers the existence of such individuals as religious people who consider the good and bad things according to their religious teachings, which in this case is Islam. Homo Islamicus does not really pursue how all his worldly needs must be maximally achieved. An Islamic human being is represented by an individual who not only considers human relationships, but also between humans and their God. This can be seen in the components of rationality in Islamic economics according to Agil (1989) described above, humans are said to be rational if their utility and consumption functions also include calculations of their obligations and morality as an Islamic human.

If we look at the components of rationality according to Agil (1989), then honestly we will agree that this is not always done by a Muslim though. Critics of Islamic economics not only come from non-Muslim economists but also from Muslim economists themselves. Mahomedy (2013) states that in fact Islamic Economics has not yet found its own identity, whether it is positioned as a branch of conventional economics, or as a separate science from conventional economics.

Sharia instruments today have indeed been widely applied, but unfortunately only in the banking and financial sectors. While in the micro and macroeconomic sphere there is still 
no real application and is used in the governance of the development of a country, even the majority Muslim countries. Islamic economic instruments such as zakat are only used as instruments of income distribution that can be said to be non-formal institutions even though they are carried out by official government bodies - commonly referred to as the Amil Zakat Board (BAZ) in each country. Yet if it refers to the components of rationality in Islamic Economics, countries with a majority Muslim population should be able to implement Islamic economics easily.

For example, Indonesia, which in fact is a country with the largest Muslim population in the world, should be able to become a center for the study of the world Islamic economy. The majority of the Muslim population certainly has rationality as explained by Agil. Therefore, the activities of economic agents in Indonesia should make it easier to implement Islam as a whole, not only applied in the banking sector, but also all matters relating to micro and macroeconomic behavior. The Indonesian government does not have to sue its residents to pay taxes in order to carry out income distribution or distribution but with the obligation to pay zakat and advice for infaq and alms should be sufficient to make all three as instruments of income distribution.

\section{Synthesis}

Rationality is an assumption that must be used in analyzing economic phenomena. All economic theories postulated by economists depart from the assumption that 'an individual or economic agent is a rational individual'. The debate about the assumption of rationality arises when classical economic theory fails to analyze and predict what individuals do when confronted with making decisions. The most intense criticism comes from behaviorist economists who state that the assumption of individuals as selfish individuals who want to win themselves to base any economic analysis is wrong. It is true that humans have basic qualities such as selfishness, but in certain conditions egoism can be suppressed in such a way that humans are not as selfish as argued by classical economists. Behaviorist economists postulate that humans have limitations that their decisions will not be what postulated by classical economists. The views of behaviorist economists who add aspects of psychology and sociology in his analysis are actually almost the same as those argued by Muslim economists who postulate Islamic economic theories. In Islamic economics, human limitations in carrying out economic activities are the rules and norms that apply as a creature created by God. Individual Muslims can not consume and produce carelessly, but he must first look at the rules in Islam.

\section{CONCLUSION}

Apart from the differences in the assumptions of rationality postulated by the three streams in economics, actually, the three assumptions of rationality from each stream of economics are complementary as we see from the criticisms received by each of the streams. Therefore, it is not appropriate to use the term 'irrationality' in criticizing the rationality approach used by each school. The irrationality of an individual when compared to other individuals would be more appropriate if it was concluded that the individual had his own measure of rationality. Not necessarily something done by individual $\mathrm{A}$ is rational for individual $\mathrm{B}$, and vice versa something that is considered irrational for individual $\mathrm{B}$ is not necessarily rational for individual $\mathrm{A}$. 


\section{REFERENCES}

Agil, S. O. S. (1989). Rationality in Economic Theory: A Critical Appraisal. In IIUM Journal of Economics and Management (Vol. 2, Issue 2, pp. 79-94).

Ashraf, M. A. (2018). Use of bounded rationality theory to understand participation of women in Islamic microfinance. Enterprise Development and Microfinance, 29(3-4), 186-208. https://doi.org/10.3362/1755-1986.18-00005

Aydin, N. (2013). Redefining Islamic Economics as a New Economic Paradigm. Islamic Economic Studies, 21(1), 1-34. https://doi.org/10.12816/0000238

Aysan, A. F., Disli, M., Duygun, M., \& Ozturk, H. (2018). Religiosity versus rationality: Depositor behavior in Islamic and conventional banks. Journal of Comparative Economics, 46(1), 1-19. https://doi.org/10.1016/j.jce.2017.03.001

Burns, T., \& Roszkowska, E. (2016). Rational Choice Theory: Toward a Psychological, Social, and Material Contextualization of Human Choice Behavior. Theoretical Economics Letters, 06(02), 195-207. https://doi.org/10.4236/tel.2016.62022

Harstad, R. M., \& Selten, R. (2014). Bounded-rationality models: Tasks to become intellectually competitive. Voprosy Ekonomiki, 2014(5), 4-26. https://doi.org/10.1257/jel.51.2.496

Hedström, P., \& Ylikoski, P. (2014). Analytical sociology and rational choice theory. Analytical Sociology: Norms, Actions and Networks, 57-50.

Isfandiar, A. A. (2015). Melacak Teori Rasionalitas Ekonomi berbasis Islamic Ethics. Muqtasid: Jurnal Ekonomi Dan Perbankan Syariah, 6(2), 23. https://doi.org/10.18326/muqtasid.v6i2.23-41

Jolls, C., Sunstein, C. R., \& Thaler, R. (1998). A Behavioral Approach to Law and Economics. Stanford Law Review, 50(5), 1471. https://doi.org/10.2307/1229304

Kuran, T. (1996). The Discontents of Islamic Economic Morality. American Economic Review, 86(2), 438-442. https://doi.org/10.2307/2118166

Mahomedy, A. C. (2013). Islamic economics: Still in search of an identity. International Journal of Social Economics, 40(6), 556-578. https://doi.org/10.1108/03068291311321857

Rabin, M. (2013). Incorporating Limited Rationality into Economics. Journal of Economic Literature, 51(2), 528-543. https://doi.org/http://dx.doi.org/10.1257/jel.51.2.528

Rudnyckyj, D. (2011). Homo economicus and homo islamicus, revisited: Islamic finance and the limits of economic reason. 8th International Conference on Islamic Economics and Finance, 1-14. http://conference.qfis.edu.qa/app/media/254

Simon, H. A. (1955). A behavioral model of rational choice. The Quarterly Journal of Economics, 69(1), 99-188.

Stanovich, K. E. (2013). Why humans are (sometimes) less rational than other animals: Cognitive complexity and the axioms of rational choice. Thinking and Reasoning, 19(1), 1-26. https://doi.org/10.1080/13546783.2012.713178

Tan, C. (2013). Rationality and autonomy from the Enlightenment and Islamic perspectives. Journal of Beliefs \& Values: Studies in Religion \& Education Post-Secularism , Religious Knowledge and Religious Education, 35(3), 327-339.

Zaroni, A. N. (2012). Landasan Filosofis Perilaku Konsumen Dalam Perspektif Ekonomi Islam Dan Konvensional. Mazahib, 10(1), 55-68. 